\title{
Effect of huitlacoche (Ustilago maydis DC Corda) paste addition on functional, chemical and textural properties of tortilla chips
}

\author{
Karla Yuritzi AMADOR-RODRÍGUEZ ${ }^{1}$, Fernando MARTÍNEZ-BUSTOS², Laura Eugenia PÉREZ-CABRERA², \\ Francisco Aníbal POSADAS-DEL-RÍO ${ }^{1}$, Norma Angélica CHÁVEZ-VELA", \\ Ma. Lorena SANDOVAL-CARDOSO ${ }^{1}$, Fidel GUEVARA-LARA ${ }^{1 *}$
}

\begin{abstract}
This study analyzed the addition of huitlacoche paste (HP) in baked tortilla chips (TC), evaluating its effects on functional, physicochemical and structural changes during processing. Two blue corn grains were nixtamalized, stone milled, air dried and milled to obtain flour; commercial blue corn flour (TM1) and commercial TC (TM2) were used as controls. Additions of 0, 3, 6 and $9 \%$ of HP were formulated; masas were prepared at 55\% moisture content (MC), precooked and baked in an industrial machine. TC crispiness was influenced by grain characteristics and percentage of HP. Huitlacoche paste addition caused an increase in total dietary fiber (from 5.27 to 14.54\%), total soluble phenolics content (from 17.52 to $37.60 \mathrm{mg} \mathrm{GAE} / 100 \mathrm{~g}$ ) and antioxidant capacity (from 6.74 to $7.98 \mu \mathrm{mol} \mathrm{TE} / \mathrm{g}$ ) in TC. Results suggest that tortilla chips added with huitlacoche can be an alternative to prepare this traditional edible fungus and produce healthier snacks, not fried and enriched with bioactive compounds.
\end{abstract}

Keywords: huitlacoche; blue corn; tortilla chips; Ustilago maydis; corn smut; functional food.

Practical Application: As obesity and diseases related to bad eating habits rise, developing sources of good nutrition and health benefits has become a major research focus in recent years. The addition of a new and functional ingredient for tortilla chips proposes to enhance the nutritional and bioactive compounds of nixtamalized corn products. Huitlacoche is an important source of fiber, lysine, essential fatty acids and bioactive compounds. Corn-based snacks increased over the last 30 years because they were included in main meals as well as in between-meal nourishments.

\section{Introduction}

Busy lifestyles and the increasing demand from consumers for meals and snacks that are quick sources of good nutrition have prompted the food industry to develop foods meeting the requirements (Reis \& Abu-Ghannam, 2014), and tortilla chips made from blue corn are a viable option (Sánchez-Madrigal et al., 2014). Tortilla chips (TC) are defined as the snacks made from milled alkaline-treated (nixtamalized) corn or alkaline-treated corn flours that are formatted, cooked, and partially dried and fried or baked (McDonough et al., 2001; Mehta, 2001). Pigmented corn contains anthocyanins and phenolic compounds which are phytochemicals synthesized in the plant by secondary metabolism; although these compounds are considered nonnutritive, interest in antioxidant and bioactive properties has increased due to their potential health benefits (Rice-Evans et al., 1996; Heinonen et al., 1998; Setchell \& Cassidy, 1999; Salinas-Moreno et al., 2003; Del Pozo-Insfran et al., 2006; He \& Giusti, 2010).

Huitlacoche (Ustilago maydis DC Corda) (also known as cuitlacoche) is a mushroom consumed traditionally in México; this dimorphic fungus is responsible for the formation of corn smut, characterized by galls or tumors principally in ears, but also in stems, leaves and tassels of the plant host (Zea mays L.)
(Bölker, 2001). Huitlacoche is a good source of protein $(10-25 \% \mathrm{db})$, with a high content of lysine; it also has a high content of dietary fiber (54-64\% db) and essential fatty acids such as linoleic and linolenic acids (Valverde et al., 1995; Beas et al., 2011). Huitlacoche has been remarked as a functional food that produces bioactive substances, the latter of which can be used to create fortified food products (Valverde et al., 1995; RuizHerrera \& Martínez-Espinoza, 1998; Valdez-Morales et al., 2010; Beas et al., 2011; Juárez-Montiel et al., 2011). Traditionally it is consumed with nixtamalized corn products, is highly edible and has no diversity processing. The objective of this research was to study the effect of huitlacoche paste addition on functional, chemical and textural properties of tortilla chips.

\section{Materials and methods}

\subsection{Materials}

Two samples of blue-kernel maize were acquired: conic variety (CG) from INIFAP (Celaya, Guanajuato, México) and creole variety (XG) from the local market of Xicotepec de Juárez, (Puebla, México). Nixtamalized commercial blue 
corn flour (TM1) (MINSA, Estado de México, México) and commercial blue baked tortilla chips (TM2) (Salmas, Sanissimo, Monterrey, N.L., México) were purchased in a local market of Aguascalientes (Aguascalientes, México); huitlacoche corn cobs were purchased in Irapuato (Guanajuato, México). Huitlacoche galls were separated from the corn cobs and cooked (stir-fried in an electric pan with no additives) for $15 \mathrm{~min}$ at $95^{\circ} \mathrm{C}$. After cooling, galls were processed into a uniform huitlacoche paste (HP) with a food processor (Quick N' Easy Processor, Black \& Decker, Shelton, CT, USA) and stored in a $-15^{\circ} \mathrm{C}$ freezer in one-liter air-tight plastic containers.

\subsection{Preparation of nixtamalized corn flour (NF) and tortilla chips (TC)}

An alkaline-cooking method was used (Salinas-Moreno \& Arellano, 1989). Briefly, maize kernels (24-kg lots) were cooked for $30 \mathrm{~min}$ in lime solution $\left[0.8 \%(\mathrm{w} / \mathrm{v}) \mathrm{Ca}(\mathrm{OH})_{2}\right.$ in distilled water] at $85{ }^{\circ} \mathrm{C}$ using a $1: 2(\mathrm{w} / \mathrm{v})$ ratio of grain to cooking medium, followed by a steeping time of $14 \mathrm{~h}$. The cooking liquor was drained and discarded and the nixtamal (alkaline-cooked maize) washed with running tap water for $40 \mathrm{~s}$. The cooked grain was ground into masa in a stone mill (M100, Fumasa, Puebla, México), and finally dehydrated using a flash type dryer (M2000, CINVESTAV-GAV, Querétaro, Qro., México).

Formulations were prepared from three nixtamalized flours (NF): conic blue corn (NCF), creole blue corn (NXF) and commercial blue corn (NMF). Each NF was added with 0 , 3,6 , and $9 \%$ of HP (w/w, db). NCF and NXF formulations were added with $0.5 \%(\mathrm{w} / \mathrm{w})$ sodium carboxymethyl cellulose (419273, Sigma-Aldrich Química, Toluca, Estado de México, México) to improve crispness, as determined from a preliminary test.

For tortilla chip processing, formulations were rehydrated to $55 \%$ water content and mixed using speed two for $10 \mathrm{~min}$ (KitchenAid ${ }^{\circledR}$ NSF Certified ${ }^{\circledR}$ Commercial Series 8-Qt Bowl Lift Stand Mixer, Benton Harbor, MI, USA). Formulations were processed in a semi-industrial tortilladora (Villamex V-100, Guadalajara, Jalisco, México; Grupo Villamex, 2003). Briefly, the masa was shaped and cut into thin triangles $(1 \mathrm{~mm}$ thickness) and the pieces were cooked on an iron hot band $\left(270^{\circ} \mathrm{C} \pm 10^{\circ} \mathrm{C}\right)$ for $45 \mathrm{~s}$ each side. After cooling, the pieces were baked in a semi-industrial convection oven at $180^{\circ} \mathrm{C}$ (Zucchelli Forni, 260493, Verona, Italy) for $15 \mathrm{~min}$, after which they were cooled and stored in air-tight packaging until evaluations and labeled: tortilla chips from NCF as CTC (conic tortilla chips); from NXF as XTC (creole tortilla chips); from NMF as MTC [MINSA (commercial flour) tortilla chips].

\subsection{Physical and proximate analyses}

The physical properties of tortilla chips were analyzed by approved AACC International methods: moisture content (MC) by method $44-15.02$, crude protein $(\% \mathrm{~N} \times 6.25)$ by method 46-10.01, crude fiber and fat (ether extract) were determined according to methods 32-10.01 and 30-10.01, respectively (American Association of Cereal Chemists, 1999). Total dietary fiber (TDF) was analyzed using the Total Dietary Fiber Assay
Kits TDF-100A and TDF-C10 (Sigma Chemical Company, St. Louis, MO, USA). Three repetitions were made for each analysis.

\subsection{Color determinations}

Color changes were determined using a MiniScan XE colorimeter (model 45/0-L, Hunter Associates Laboratory, Reston, VA, USA). Total color differences $(\Delta \mathrm{E})$ at the different periods of time were calculated from the determined CIELAB $L^{\star} a^{*} b^{\star}$ values according to Equation 1 .

$$
\Delta \mathrm{E}=\left[(\Delta \mathrm{L} *)^{2}+(\Delta \mathrm{a} *)^{2}+(\Delta \mathrm{b} *)^{2}\right]^{1 / 2}
$$

where $\mathrm{L}^{*}=$ brightness or lightness $(100=$ perfect white, to $0=$ black); $\mathrm{a}^{*}=$ greenness/redness [negative (green) to positive (red)]; $\mathrm{b}^{*}=$ yellowness/blueness [negative (blue) to positive (yellow) ]; $\Delta \mathrm{L}^{*}, \Delta \mathrm{a}^{*}$, and $\Delta \mathrm{b}^{*}=$ absolute differences of the values between the reference tile (white porcelain) and sample values; $\Delta \mathrm{E}=$ total difference between reference and sample color. The reference (calibration) values were: $\mathrm{L}^{*}=92.22, \mathrm{a}^{*}=0.82$ and $\mathrm{b}^{*}=0.62$. Color measurements were repeated five times at each experimental condition.

\subsection{Total soluble phenolics contents}

Total soluble phenolics of samples was determined using a colorimetric method (Singleton et al., 1999). A calibration curve of gallic acid using 30\% (v/v) methanol as solvent was used. Sample extracts were prepared accordingly using $500 \mathrm{mg}$ of sample homogenized with $10 \mathrm{~mL}$ of $30 \%(\mathrm{v} / \mathrm{v})$ methanol and agitated for $1.5 \mathrm{~h}$. The extracts were centrifuged at $3200 \times \mathrm{g}$ (Thermo IEC model CL3-R, USA) for $30 \mathrm{~min}$ and decanted. Thirty microliters of extract, $3 \mathrm{~mL}$ of deionized water, and $200 \mu \mathrm{L}$ of Folin-Ciocalteu's phenol reagent were mixed and allowed to stand for $10 \mathrm{~min}$ at room temperature. The reaction was neutralized with $600 \mu \mathrm{L}$ of a $20 \%(\mathrm{w} / \mathrm{v})$ sodium carbonate solution. The mixture was incubated for $20 \mathrm{~min}$. The absorbance was measured at $757 \mathrm{~nm}$ using a spectrophotometer (BioMate 3 , Thermo Fisher Technologies, Wisconsin, USA), and a reagent blank was used. The results were expressed as milligrams of gallic acid equivalents per $100 \mathrm{~g}$ of sample (mg GAE/100 g). This determination was performed in triplicate for each extract.

\subsection{Total anthocyanins}

Total anthocyanins were assayed according to Abdel-Aal \& Hucl (1999) by measuring the absorbance of ethanolic extracts. Tortilla chip samples $(1.5 \mathrm{~g})$ were homogenized with $10 \mathrm{~mL}$ of an acidified ethanol solution (ethanol and $1 \mathrm{~N} \mathrm{HCl}, 85: 15$, v/v). The solution was mixed and adjusted to $\mathrm{pH} 1$ with $4 \mathrm{~N} \mathrm{HCl}$, agitated for $30 \mathrm{~min}$, and then centrifuged at $3200 \times g$ (Sorvall RC5C, Sorvall Instruments, Dupont, Wilmington, DE, USA). The supernatant was poured into a $25 \mathrm{~mL}$ volumetric flask and brought to volume with acidified ethanol. The absorbance was measured at $535 \mathrm{~nm}$ using a spectrophotometer (BioMate 3, Thermo Fisher Technologies, Wisconsin, USA), and a reagent blank was used. The total anthocyanin content was expressed 
as milligrams of cyanidin 3-glucoside per kilogram of sample ( $\mathrm{mg} \mathrm{C} 3 \mathrm{G} / \mathrm{kg}$ ) and was calculated using Equation 2:

$$
\begin{aligned}
& \mathrm{C}=\left[\left(\mathrm{A}_{535 \mathrm{~nm}}-\mathrm{A}_{700 \mathrm{~nm}}\right) / \varepsilon\right] \times(\text { total volume of extract } / 1000) \times \\
& \operatorname{MW}(1 / \text { sample wt }) * 10^{6}
\end{aligned}
$$

Where $\mathrm{C}$ is the concentration of total anthocyanin expressed as milligrams of cyanidin-3-glucoside ( $\mathrm{mg} \mathrm{C} 3 \mathrm{G}$ ) per kilogram of sample; $\varepsilon$ is the molar absorptivity for cyanidin-3-glucoside $\left(25965 \mathrm{~cm}^{-1} \mathrm{~mol}^{-1}\right)$ and MW is the molecular weight of cyanidin3-glucoside, $449 \mathrm{Da}$.

\subsection{Trolox equivalent antioxidant capacity (TEAC)}

Antioxidant capacity was evaluated following the TEAC-DPPH method (Brand-Williams et al., 1995; Fukumoto \& Mazza, 2000). A calibration curve of $1 \mathrm{mM}$ Trolox was used. The extracts were prepared in darkness using a procedure similar to that described for the determination of phenolics content, except that absolute methanol was used. An aliquot of $600 \mu \mathrm{L}$ of DPPH in methanol was added to $100 \mu \mathrm{L}$ of extract. The mixture was allowed to stand at room temperature in the dark for $20 \mathrm{~min}$, after which absorbance at $515 \mathrm{~nm}$ was measured using a spectrophotometer (BioMate 3, Thermo Fisher Technologies, Wisconsin, USA). Results were expressed as micromoles of Trolox equivalents per gram of sample $(\mu \mathrm{mol} \mathrm{TE} / \mathrm{g})$. This determination was performed in triplicate for each extract.

\subsection{Breaking force}

Tortilla chip texture was evaluated using a texture analyzer with a Kramer shear cell. A 454-gram load cell was used. The probe of the cell traveled at $5 \mathrm{~cm} / \mathrm{min}$. One piece of tortilla chip was placed in the Kramer shear cell for testing. Breaking forces until peak values were obtained from time-deformation curves.

\subsection{Statistical analyses}

All results were expressed as means \pm standard deviation values $(n=3)$. Statistical comparisons between two groups were made by using Student's $t$ test. With several groups, one-way analysis of variance was used; Tukey's analyses $(\mathrm{p}<0.05)$ were applied for means with significant differences, and Pearson correlation was calculated. The data were analyzed using the GraphPad Prism Version 5.0 software package (GraphPad Software, Inc., San Diego, CA, USA).

\section{Results and discussion}

\subsection{Color determinations}

Tortilla chips (TC) darkened as added HP level increased (Table 1) in the formulation. TC presented $\mathrm{L}^{*}$ values ranging from 30 to 59, similar values were reported for fleshed cooked huitlacoche (Martínez-Flores et al., 2008). Positive $a^{*}$ values were observed, corresponding to different tonalities of red, and these values were higher as HP was added, than those of the nixtamalized flours, thus, indicating the presence of a greenish tint in the latter, which is attributable to the nixtamalization process. The best blue maize varieties for the elaboration of naturally tinted nixtamalized products are those which present the least change in the $\mathrm{a}^{*}$ value after nixtamalization (SalinasMoreno et al., 2003). In all of the raw materials measurements, positive $b^{*}$ values were observed too; the HP addition increased the $b^{*}$ (yellowness) values as well. Sánchez-Madrigal et al. (2014) reported values of 30.25-31.43 $\mathrm{L}^{*}, 7.78-11.97 \mathrm{a}^{*}$ and $2.18-8.3 \mathrm{~b}^{*}$ for blue corn tortilla chips. $L^{\star}$ values decreased as compared to nixtamalized corn flours. During the alkaline cooking process anthocyanins are destroyed, mainly in maize with pigment in the pericarp. In the blue grain maize, the nixtamalization process provokes darkening of the flour, whereas in the case of red maize, the process does not affect the color. Nixtamalization modifies the anthocyanin pattern, thus increasing the relative percentage of the 3-glucoside anthocyanin in blue maize varieties

\begin{tabular}{|c|c|c|c|c|}
\hline Tortilla Chip & $\mathrm{L}^{*}$ & $a^{*}$ & $\mathrm{~b}^{*}$ & $\Delta \mathrm{E}$ \\
\hline CTC-0 & $43.2 \pm 1.87 \mathrm{ab}$ & $3.14 \pm 0.32 \mathrm{abc}$ & $6.9 \pm 1.61 \mathrm{e}$ & $52.6 \pm 6.58 \mathrm{ab}$ \\
\hline CTC-3 & $39.9 \pm 3.21 \mathrm{bcd}$ & $3.36 \pm 0.37 \mathrm{abc}$ & $10.7 \pm 1.89 \mathrm{~cd}$ & $45.0 \pm 3.39 \mathrm{a}$ \\
\hline CTC-6 & $35.7 \pm 3.54 \mathrm{~cd}$ & $3.75 \pm 0.38 \mathrm{a}$ & $13.1 \pm 0.61 \mathrm{ab}$ & $57.4 \pm 3.38 \mathrm{a}$ \\
\hline CTC-9 & $29.8 \pm 1.17 \mathrm{e}$ & $3.80 \pm 0.18 \mathrm{a}$ & $11.4 \pm 0.29 \mathrm{abc}$ & $59.4 \pm 3.70 \mathrm{a}$ \\
\hline XTC-0 & $46.1 \pm 4.78 \mathrm{a}$ & $2.19 \pm 0.85 f$ & $7.4 \pm 0.82 \mathrm{e}$ & $46.8 \pm 3.69 b$ \\
\hline XTC-3 & $42.1 \pm 6.22 \mathrm{abc}$ & $2.45 \pm 0.48 \mathrm{ef}$ & $11.1 \pm 2.09 \mathrm{abc}$ & $52.7 \pm 6.45 \mathrm{ab}$ \\
\hline XTC-6 & $37.9 \pm 2.69 \mathrm{bcd}$ & $2.80 \pm 0.28 \mathrm{de}$ & $13.6 \pm 0.80 \mathrm{a}$ & $56.0 \pm 2.36 \mathrm{a}$ \\
\hline XTC-9 & $36.3 \pm 3.36 \mathrm{~cd}$ & $2.88 \pm 0.35 \mathrm{cde}$ & $12.8 \pm 0.84 \mathrm{ab}$ & $56.4 \pm 4.38 \mathrm{a}$ \\
\hline TM1-0 & $42.1 \pm 2.16 \mathrm{abc}$ & $3.72 \pm 0.40 \mathrm{ab}$ & $3.8 \pm 0.90 \mathrm{f}$ & $53.5 \pm 3.85 \mathrm{ab}$ \\
\hline TM1-3 & $40.5 \pm 3.61 \mathrm{abcd}$ & $3.55 \pm 0.23 \mathrm{a}$ & $9.0 \pm 0.98 \mathrm{de}$ & $52.6 \pm 4.23 \mathrm{ab}$ \\
\hline TM1-6 & $36.5 \pm 1.95 \mathrm{~cd}$ & $3.42 \pm 0.19 \mathrm{abc}$ & $10.3 \pm 0.98 \mathrm{~cd}$ & $58.5 \pm 1.29 \mathrm{a}$ \\
\hline TM1-9 & $34.3 \pm 1.58 \mathrm{~d}$ & $3.38 \pm 0.21 \mathrm{abc}$ & $10.3 \pm 0.92 \mathrm{~cd}$ & $56.0 \pm 3.98 \mathrm{a}$ \\
\hline TM2 & $41.1 \pm 1.16 \mathrm{abc}$ & $3.69 \pm 0.35 \mathrm{ab}$ & $3.5 \pm 0.60 \mathrm{f}$ & $52.5 \pm 3.15 \mathrm{ab}$ \\
\hline
\end{tabular}

Table 1. Color of blue-corn tortilla chips added with huitlacoche.

Abbreviations: $\mathrm{L}^{*}$ (brightness or lightness, $100=$ perfect white, $0=$ black), $\mathrm{a}^{*}$ [greenness (negative) to redness (positive)], $\mathrm{b}^{*}$ [blueness (negative) to yellowness (positive)], $\Delta \mathrm{E}$ [total difference between reference (white tile) and sample color], CTC (conic corn tortilla chip), XTC (creole corn tortilla chip), TM1 (commercial flour tortilla chip), TM2 (commercial blue corn tortilla chip); $0,3,6$ and $9 \%$ of huitlacoche paste (HP) added. Results presented as mean $(\mathrm{n}=3) \pm$ standard deviation; means with the same letter in the same column are not significantly different $(\mathrm{P}<0.05)$, Student-Newman-Keuls analysis. 
(Salinas-Moreno et al., 2003). The frying or baking processes cause darkening due to the Maillard reaction or caramelization (Maga \& Liu, 1993; Buttery \& Ling, 1995).

\subsection{Breaking force}

Fracture forces for baked chips were significantly different among the different blue corn flours used $(\mathrm{P}<0.05)$. CTC showed the highest resistance to fracture or hardness (22.84-27.54 kgf); and XTC formulations showed less resistance to fracture (13.10-20.91 kgf); this difference can be attributed to the formation of complexes of starch with calcium resulting in a more compact molecule and therefore harder tortilla chips (Gomez et al., 1991; ZazuetaMorales et al., 2002). TM1 had the lowest value (8.72-16.25 kgf) and this may be due to the additives (carboxymethyl cellulose and/ or guar gum) declared in the label. Fracture force was inversely correlated to protein content $(\mathrm{r}=-0.879)$ and directly to oil content $(r=0.952)$. Singh et al. (1996) reported that the force required to compress the product increased in direct proportion to the soya flour in the dough. The texture properties of tortilla chips is related to the removal of moisture during the baking process at high temperatures, which leads to the formation of larger air cells and cracks in the structure resulting in low fracture force values (Sánchez-Madrigal et al., 2014). This is because at high temperatures, large cracks are formed due to the quick vaporization and diffusion of moisture through the pores (Kayacier \& Singh, 2003). High peak load force values (50 to $140 \mathrm{kgf}$ ) were reported in baked tortilla chips made from commercial nixtamalized instant-masa flours (not blue color) (Kayacier \& Singh, 2003). Plascencia-González et al. (1999) produced corn tortilla chips from lime-cooked blue maize with good sensory characteristics (color, flavor and texture).

The texture properties of tortilla chips is related to the removal of moisture during the baking process at high temperatures, which leads to the formation of larger air cells and cracks in the structure resulting in low fracture force values (SánchezMadrigal et al., 2014). This is because at high temperatures, large cracks are formed due to the quick vaporization and diffusion of moisture through the pores (Kayacier \& Singh 2003).

Huitlacoche addition influences the breaking force as the addition increases, the high content of dietary fiber (54-64\% db) of huitlacoche (Valverde et al., 1995; Beas et al., 2011) may influence the water absorption index. The boiling temperature of water inside the sample increased quickly at high temperature and high pressure causing larger cracks (Kayacier \& Singh, 2003).

\subsection{Proximate analyses}

Some chemical characteristics of tortilla chips were also evaluated (Table 2). Crude fat was reduced as huitlacoche increased. Protein content of tortilla chips did not change significantly with the addition of huitlacoche $(\mathrm{P}<0.05)$, but it showed significant differences among raw materials. XTC showed the lowest amount of crude protein (6\%) while commercial tortilla chips showed the highest. Total dietary fiber and crude fiber were incremented by the HP addition $(\mathrm{P}<0.05)$; total dietary fiber content was influenced by the flour used and by the addition of HP. Commercial tortilla chips (TM2) reported $5.5 \%$ of TDF in the label, while the treatments almost tripled this value, as CTC-9 shows. Levels of $2.9 \mathrm{~g}$ oil $/ 100 \mathrm{~g}$ sample, $12.4 \mathrm{~g}$ protein/100 g and 54-64\% total dietary fiber have been reported for raw huitlacoche (Beas et al., 2011), while those reported for blue corn were $4.2-4.8 \%$ oil and $9.5-10.4 \%$ protein, respectively (Salinas-Moreno et al., 2013). Crude fat was negatively correlated to anthocyanin content $(\mathrm{r}=-0.7430)$ because these pigments are water soluble (Wrolstad et al., 2005).

\subsection{Total soluble phenolics, anthocyanin content and TEAC}

The functional properties of raw materials were evaluated (Table 3). Nixtamalization did not result in significant differences $(\mathrm{P}<0.05)$ in total soluble phenolics contents; from grains to nixtamalized corn flours, these contents ranged from 84 to $92 \mathrm{mg} \mathrm{GAE} / 100 \mathrm{~g}$ sample (db). Huitlacoche decreased its phenolics content from 538 to $393 \mathrm{mg} \mathrm{GAE} / 100 \mathrm{~g}$ sample (db)

Table 2. Crude fat, protein, fiber and moisture contents of tortilla chips.

\begin{tabular}{|c|c|c|c|c|}
\hline Tortilla Chip & $\begin{array}{c}\text { Crude Fat } \\
(\%)\end{array}$ & $\begin{array}{c}\text { Crude Protein } \\
(\%)\end{array}$ & $\begin{array}{c}\text { Total Dietary Fiber } \\
(\%)\end{array}$ & $\begin{array}{c}\text { Moisture Content } \\
(\%)\end{array}$ \\
\hline CTC-0 & $3.20 \pm 0.12 \mathrm{f}$ & $10.1 \pm 0.04 b$ & $10.34 \pm 0.01 \mathrm{f}$ & $2.87 \pm 0.01 \mathrm{c}$ \\
\hline CTC-3 & $3.08 \pm 0.09 f$ & $10.1 \pm 0.02 b$ & $13.00 \pm 0.01 \mathrm{c}$ & $2.68 \pm 0.01 \mathrm{de}$ \\
\hline CTC-6 & $2.70 \pm 0.04 \mathrm{~g}$ & $10.2 \pm 0.11 b$ & $13.54 \pm 0.01 b$ & $2.48 \pm 0.01 \mathrm{ef}$ \\
\hline CTC-9 & $2.48 \pm 0.01 \mathrm{~h}$ & $10.0 \pm 0.04 b$ & $14.54 \pm 0.01 \mathrm{a}$ & $2.28 \pm 0.01 f$ \\
\hline XTC-0 & $3.61 \pm 0.03 b$ & $6.50 \pm 0.01 d$ & $7.97 \pm 0.01 \mathrm{j}$ & $3.00 \pm 0.02 \mathrm{~cd}$ \\
\hline XTC-3 & $3.48 \pm 0.03 b$ & $6.68 \pm 0.09 \mathrm{~cd}$ & $9.67 \pm 0.01 \mathrm{~g}$ & $2.87 \pm 0.13 \mathrm{~cd}$ \\
\hline XTC-6 & $3.21 \pm 0.04 \mathrm{c}$ & $6.69 \pm 0.10 \mathrm{~cd}$ & $10.97 \pm 0.01 \mathrm{e}$ & $2.62 \pm 0.15 \mathrm{de}$ \\
\hline XTC-9 & $2.93 \pm 0.18 \mathrm{~d}$ & $6.76 \pm 0.02 c$ & $11.72 \pm 0.01 \mathrm{~d}$ & $2.50 \pm 0.02 \mathrm{ef}$ \\
\hline TM1-0 & $2.44 \pm 0.14 \mathrm{c}$ & $8.38 \pm 0.07 \mathrm{~g}$ & $5.27 \pm 0.01 \mathrm{~m}$ & $3.81 \pm 0.13 a$ \\
\hline TM1-3 & $2.30 \pm 0.18 \mathrm{~cd}$ & $8.56 \pm 0.03 f$ & $6.93 \pm 0.01 \mathrm{k}$ & $2.92 \pm 0.07 \mathrm{~cd}$ \\
\hline TM1-6 & $1.92 \pm 0.09 \mathrm{e}$ & $8.57 \pm 0.05 f$ & $8.90 \pm 0.01 \mathrm{i}$ & $2.77 \pm 0.15 \mathrm{de}$ \\
\hline TM1-9 & $1.69 \pm 0.02 f$ & $8.75 \pm 0.00 \mathrm{e}$ & $9.20 \pm 0.01 \mathrm{~h}$ & $2.98 \pm 0.10 \mathrm{~cd}$ \\
\hline TM2 & $5.55 \pm 0.03 \mathrm{a}$ & $11.1 \pm 0.10 \mathrm{a}$ & $5.55 \pm 0.011$ & $2.70 \pm 0.07 \mathrm{~b}$ \\
\hline
\end{tabular}

Abbreviations: CTC (conic corn tortilla chip), XTC (creole corn tortilla chip), TM1 (commercial flour tortilla chip), TM2 (commercial blue corn tortilla chip); $0,3,6$ and $9 \%$ of huitlacoche paste (HP) added. Results presented as mean $(n=3) \pm$ standard deviation; means with the same letter in the same column are not significantly different $(\mathrm{P}<0.05)$, StudentNewman-Keuls analysis. 
as an effect of the cooking process. Previously reported values in raw huitlacoche include 390-640 mg GAE/100 g for total soluble phenolics (Beas et al., 2011). Compared to other foods, huitlacoche presented higher soluble phenolics content than some bean varieties (141-198 mg/100 g db) (Vinson et al., 2001).

Thermal processing resulted in losses of anthocyanins during nixtamalization. CG and XG showed anthocyanin contents of 287.2 and $336.0 \mathrm{mg} \mathrm{C} 3 \mathrm{GE} / \mathrm{kg}$, respectively; those values decreased dramatically to 78.6 and $21.8 \mathrm{mg} \mathrm{C} 3 \mathrm{GE} / \mathrm{kg}$ for the NCF and NXF nixtamalized flours, respectively. As a reference, NMF showed $102.1 \mathrm{mg} \mathrm{C} 3 \mathrm{GE} / \mathrm{kg}$. Anthocyanin losses were probably influenced by the grain type; XG, a soft grain corn, lost more anthocyanin than CG, which has harder grains. Some researchers have found different anthocyanin concentrations in pigmented corn grains ranging from low content (10-33 mg C3GE/kg), medium content (60-159 mg C3GE/kg) to high content (324-3045 mg C3GE/kg) (Agama-Acevedo et al., 2004; Abdel-Aal et al., 2006; Del PozoInsfran et al., 2006; López-Martínez \& García-Galindo, 2009; López-Martínez et al., 2011; Escalante-Aburto et al., 2013). $\mathrm{FH}$ and HP showed no significant differences in anthocyanin contents (Table 3). Beas et al. (2011) reported anthocyanin levels in huitlacoche from 71 to $226 \mathrm{mg} / \mathrm{kg}$ C3EG (db).

The raw materials showed significant differences in antioxidant capacity (Table 3 ). Fresh huitlacoche and its paste had the highest TEAC values: 88.8 and $64.4 \mu \mathrm{mol} \mathrm{TE} / \mathrm{g}$ sample, respectively. Among blue-corn grains and nixtamalized flours, creole grains (XG) and their nixtamalized flour (NXF) had the highest TEAC (16.3 and $17.0 \mu \mathrm{mol} \mathrm{TE} / \mathrm{g}$, respectively).

Total soluble phenolics contents in tortilla baked chips were significantly different among the various blue-corn masas analyzed $(\mathrm{P}<0.05$; Figure 1). HP increased the total soluble phenolics content as it was increased from 0 to $9 \%(\mathrm{db})$ in the three nixtamalized corn flours used. CTC showed increasing total phenolics levels of 17.52, 20.46, 26.01 and $36.08 \mathrm{mg} \mathrm{GAE} / 100 \mathrm{~g}$ sample as the HP was added at $0,3,6$ and $9 \%$, respectively; similar behaviors were shown by XTC and TM1. As a reference, the commercial tortilla chip (TM2) contained $20.5 \mathrm{mg}$ GAE/100 g of sample.

Table 3. Total soluble phenolics, anthocyanin content and Trolox equivalent antioxidant capacity of raw materials.

\begin{tabular}{lccr}
\hline Sample & $\begin{array}{c}\text { Total Soluble } \\
\text { Phenolics Content } \\
(\mathrm{mg} \mathrm{GAE} / 100 \mathrm{~g})\end{array}$ & $\begin{array}{c}\text { Anthocyanin } \\
\text { Content } \\
(\mathrm{mg} \mathrm{C} 3 \mathrm{GE} / \mathrm{kg})\end{array}$ & \multicolumn{1}{c}{$\begin{array}{c}\text { TEAC } \\
(\mu \mathrm{mol} \mathrm{TE} / \mathrm{g})\end{array}$} \\
\hline CG & $84.74 \pm 2.48 \mathrm{c}$ & $287.2 \pm 7.44 \mathrm{~b}$ & $8.5 \pm 0.02 \mathrm{~g}$ \\
XG & $88.33 \pm 0.65 \mathrm{c}$ & $336.0 \pm 13.90 \mathrm{a}$ & $16.3 \pm 0.00 \mathrm{~d}$ \\
NCF & $86.34 \pm 1.53 \mathrm{c}$ & $78.6 \pm 1.73 \mathrm{~d}$ & $8.9 \pm 0.00 \mathrm{f}$ \\
NXF & $92.44 \pm 1.27 \mathrm{c}$ & $21.8 \pm 1.70 \mathrm{e}$ & $17.0 \pm 0.00 \mathrm{c}$ \\
TM1 & $85.66 \pm 4.30 \mathrm{c}$ & $102.1 \pm 6.53 \mathrm{c}$ & $9.3 \pm 0.00 \mathrm{e}$ \\
FH & $538.34 \pm 29.22 \mathrm{a}$ & $30.4 \pm 0.86 \mathrm{e}$ & $88.8 \pm 0.00 \mathrm{a}$ \\
HP & $393.25 \pm 3.79 \mathrm{~b}$ & $30.3 \pm 1.91 \mathrm{e}$ & $64.4 \pm 0.01 \mathrm{~b}$ \\
\hline
\end{tabular}

Abbreviations: GAE (gallic acid equivalents), C3GE (cyanidin-3-glucoside equivalents), TEAC (Trolox equivalent antioxidant capacity), TE (Trolox equivalents), CG (conic grain), XG (creole grain), NCF (nixtamalized conic corn flour), NXF (nixtamalized creole corn flour), TM1 (nixtamalized commercial flour), FH (fresh huitlacoche), HP (huitlacoche paste). Results presented as mean $(\mathrm{n}=3) \pm$ standard deviation; means with the same letter in the same column are not significantly different $(\mathrm{P}<0.05)$, StudentNewman-Keuls analysis.
Some studies have reported that the presence of polyphenolics such as catechin and free forms of ferulic acid in corn flours contribute to the antioxidant activity (De la Parra et al., 2007; López-Martínez et al., 2009).

Total anthocyanin contents in baked tortilla chips were significantly different among the various nixtamalized bluecorn flours $(\mathrm{P}<0.05$; Figure 2$)$. However, HP did not modify the total anthocyanin content as it was added from 0 to $9 \%(\mathrm{db})$ in the nixtamalized corn flours used. TM1 and TM2 showed the highest contents (49.48-55.10 mg C3GE/kg).

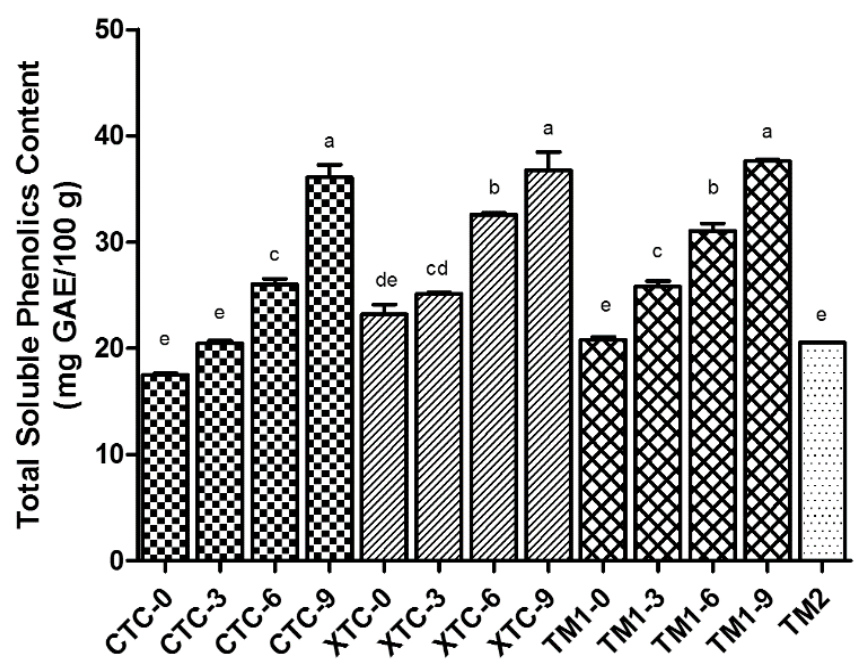

Figure 1. Total soluble phenolics in tortilla chips added with huitlacoche at $0,3,6$ and $9 \%(\mathrm{db})$. GAE (gallic acid equivalents), CTC (conic corn tortilla chip), XTC (creole corn tortilla chip), TM1 (commercial flour tortilla chip), TM2 (commercial blue corn tortilla chip); 0, 3, 6 and 9\% of huitlacoche paste (HP) added. Means $(n=3)$ with the same letter are not significantly different $(\mathrm{P}<0.05)$, Student-Newman-Keuls analysis.

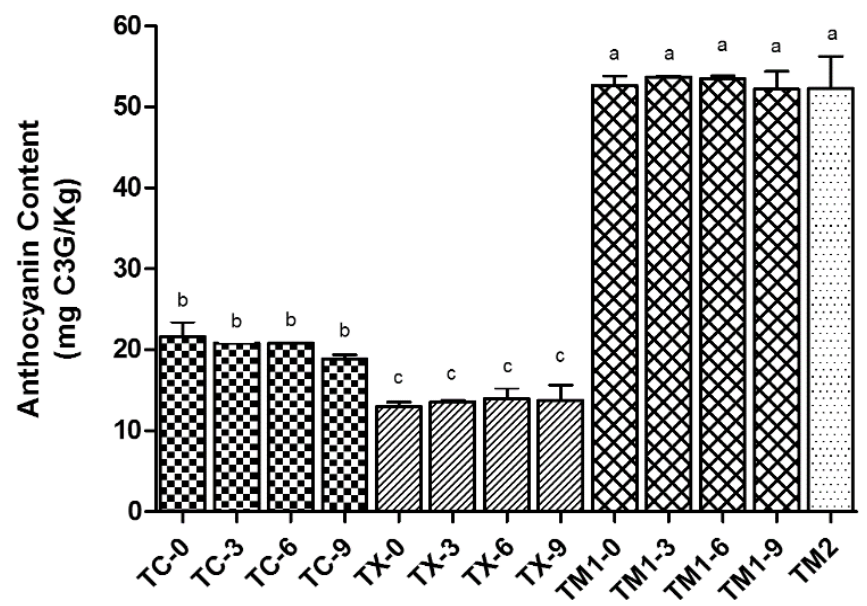

Figure 2. Anthocyanin contents in tortilla chips added with huitlacoche at $0,3,6$ and $9 \%(\mathrm{db})$. C3GE (cyanidin-3-glucoside equivalents), CTC (conic corn tortilla chip), XTC (creole corn tortilla chip), TM1 (commercial flour tortilla chip), TM2 (commercial blue corn tortilla chip); $0,3,6$ and $9 \%$ of huitlacoche paste (HP) added. Means $(n=3)$ with the same letter are not significantly different $(\mathrm{P}<0.05)$, StudentNewman-Keuls analysis. 


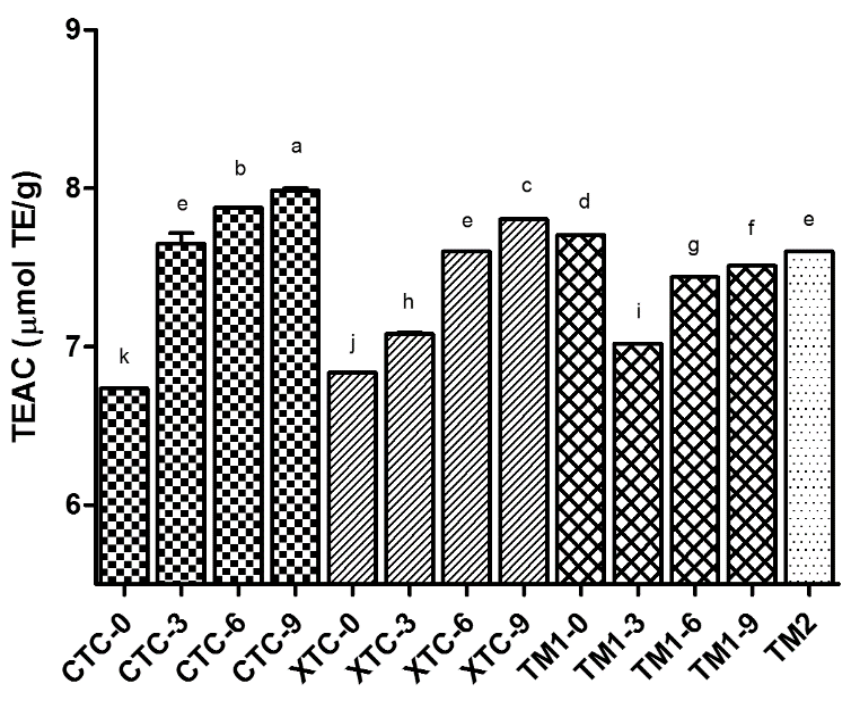

Figure 3. Trolox equivalent antioxidant capacity (TEAC) for tortilla chips added with huitlacoche at $0,3,6$ and $9 \%$ (db). TE (Trolox equivalents), CTC (conic corn tortilla chip), XTC (creole corn tortilla chip), TM1 (commercial flour tortilla chip), TM2 (commercial blue corn tortilla chip); $0,3,6$ and $9 \%$ of huitlacoche paste (HP) added. Means $(n=3)$ with the same letter are not significantly different $(\mathrm{P}<0.05)$, StudentNewman-Keuls analysis.

Figure 3 shows that TEAC values for baked tortilla chips were significantly different among the different formulations with HP $(\mathrm{P}<0.05)$. HP increased the antioxidant capacity of the tortilla chips as it was added at 3,6 and $9 \%(\mathrm{db})$ to the three nixtamalized corn flours. The antioxidant capacity of CTC increased as the HP was added, showing values of $6.74,7.72$, 7.88 and $7.98 \mu \mathrm{mol} \mathrm{TE} / \mathrm{g}$ sample at $0,3,6$ and $9 \%$ of addition, respectively. XTC increased as well from 6.84 to $7.80 \mu \mathrm{mol}$ TE/g sample. TM1 showed a different behavior, TM1-0 had $7.70 \mu \mathrm{mol} \mathrm{TE} / \mathrm{g}$ sample, then the antioxidant capacity decreased in TM1-3 down to $7.02 \mu \mathrm{mol} \mathrm{TE} / \mathrm{g}$ sample, and incrementing again from $7.44 \mu \mathrm{mol}$ TE/g sample in TM1-6 up to $7.51 \mu \mathrm{mol}$ TE/g sample in TM1-9. As a reference, the commercial tortilla chip (TM2) had $7.59 \mu \mathrm{mol}$ TE/g sample. TM2 declared in the label: nixtamalized blue corn flours, salt (1\%) and tocopherols (natural antioxidant). TEAC was negatively correlated to the $\mathrm{L}^{*}$ parameter $(r=-0.7382)$, while total soluble phenolics content was negatively correlated to $\mathrm{L}^{*}(\mathrm{r}=-0.7722)$ and positively to $\mathrm{b}^{\star}$ values $(\mathrm{r}=0.7038)$; the addition of HP and its black color influenced $\mathrm{L}^{\star}$; on the other hand $\mathrm{b}^{\star}$ may have been influenced by blue corn. Sánchez-Madrigal et al. (2014) reported antioxidant capacities from 0.5 to $1.2 \mu \mathrm{mol} \mathrm{TE} / \mathrm{g}$ in blue corn tortilla chips from extruded flours containing different sources of calcium.

Several works have also found that nixtamalization significantly reduces the total polyphenol content, antioxidant activity and anthocyanin content in corn and corn products, due to the thermal-alkaline process and by the leaching of these same compounds to the nejayote (Salinas-Moreno et al., 2003; Del Pozo-Insfran et al., 2006; De la Parra et al., 2007; MoraRochin et al., 2010).

Meanwhile, López-Martínez et al. (2011) found a decrease in anthocyanins and phenolics due to the alkaline heat treatment in some varieties, and demonstrating that the loss of anthocyanins is associated with the variety of corn used; these authors also reported an increase in antioxidant capacity after cooking the tortilla dough preparation, due likely to an increase in soluble phenolics. Snacks produced with colored flour had 2-3 times higher antioxidant activities, $40 \%$ higher contents of polyphenols, attractive color and better expansion compared to control samples (Nemś et al., 2015).

Anthocyanin and phenolic contents have shown a high correlation with antioxidant activity and color of tortilla chips (Sánchez-Madrigal et al., 2014), however, in our work the commercial flour and tortilla chips showed no correlation among those parameters. Mexican official regulation (NOM187-SSA1/SCFI-2002; México, 2003) allows for the addition of a mixture of artificial colors; their sum should not exceed $500 \mathrm{mg} / \mathrm{kg}$ of product in tortillas; for tortilla chips, brilliant blue FCF1 is allowed ( $300 \mathrm{mg} / \mathrm{kg}$ maximum), and for flours no color addition is allowed.

\section{Conclusions}

The huitlacoche fungus is a valuable source of phenolic compounds and antioxidants. Its application as ingredient in the formulation of baked snacks resulted in an increase in the phenolic and in the antioxidant properties when compared to the controls without huitlacoche and to commercial tortilla chips. However, the heat treatment applied in precooking pieces and convection oven promoted loss of phenolic compounds, anthocyanins and antioxidant capacity. The functional, physicochemical and structural properties of tortilla chips changed significantly with the addition of huitlacoche (Ustilago maydis). The functional properties of tortilla chips were enhanced because of the huitlacoche phytochemical contents, which are related to health benefits. Thus, huitlacoche can be used as ingredient in the formulation of baked corn snacks generating products richer in antioxidants, phenolic compounds and fiber.

\section{Acknowledgements}

We thank financial support from CONACyT-México to KYAR, from Universidad Autónoma de Aguascalientes (proj. PIBT11-4 and PIBT14-2), and PROMEP, Secretaría de Educación Pública, México. Technical support from José Juan Véles Medina, Edmundo Gutiérrez Arias, José Eleazar Urbina Álvarez and CINVESTAV-Unidad Querétaro is also acknowledged.

\section{References}

Abdel-Aal, E. S. M., \& Hucl, P. (1999). A rapid method for quantifying total anthocyanins in blue aleurone and purple pericarp wheats. Cereal Chemistry, 76(3), 350-354. http://dx.doi.org/10.1094/ CCHEM.1999.76.3.350.

Abdel-Aal, S. M., Young, J. C., \& Rabalski, I. (2006). Anthocyanin composition in black, blue, pink, purple, and red cereal grains. Journal of Agricultural and Food Chemistry, 54(13), 4696-4704. http://dx.doi.org/10.1021/jf0606609. PMid:16787017.

Agama-Acevedo, E., Ottenhof, M. A., Farhat, M. I., Paredes-López, O., Ortíz-Cereceres, J., \& Bello-Pérez, L. A. (2004). Efecto de la nixtamalización sobre las características moleculares del almidón 
de variedades pigmentadas de maíz. Interciencia, 29(11), 643-649. Retrieved from http://www.interciencia.org/v29_11/index.html

American Association of Cereal Chemists - AACC International. (1999). Approved methods of analysis (11th ed.). St. Paul: AACC International. Retrieved from http://methods.aaccnet.org/default.aspx

Beas, F. R., Guevara, L. F., Vasco, M. N. L., Loarca, P. G., Rodríguez, M. G., \& Guzmán, M. S. H. (2011). Potencial nutracéutico de componentes bioactivos presentes en huitlacoche de la zona centro de México. Revista Mexicana de Ciencias Farmacéuticas, 42(2), 36-44. Retrieved from http://www.scielo.org.mx/pdf/rmcf/v42n2/v42n2a6.pdf

Bölker, M. (2001). Ustilago maydis - a valuable model system for the study of fungal dimorphism and virulence. Microbiology-SGM, 147(6), 1395-1401. Retrieved from http://mic.sgmjournals.org/ content/147/6/1395.full

Brand-Williams, W., Cuvelier, M. E., \& Berset, C. (1995). Use of a free radical method to evaluate antioxidant activity. LebensmittelWissenschaft Und-Technologie, 28(1), 25-30. Retrieved from http:// www.sciencedirect.com/science/article/pii/S0023643895800085

Buttery, R. G., \& Ling, L. C. (1995). Volatile flavor components of corn tortillas and related products. Journal of Agricultural and Food Chemistry, 43(7), 1878-1882. http://dx.doi.org/10.1021/jf00055a023.

De la Parra, C., Saldivar, S. O. S., \& Liu, R. H. (2007). Effect of processing on the phytochemical profiles and antioxidant activity of corn for production of masa, tortillas, and tortilla chips. Journal of Agricultural and Food Chemistry, 55(10), 4177-4183. http://dx.doi.org/10.1021/ jf063487p. PMid:17455952.

Del Pozo-Insfran, D., Brenes, C. H., Serna Saldívar, S. O., \& Talcott, S. T. (2006). Polyphenolic and antioxidant content of white and blue corn (Zea mays L.) products. Food Research International, 39(6), 696-703. http://dx.doi.org/10.1016/j.foodres.2006.01.014.

Escalante-Aburto, A., Ramírez-Wong, B., Torres-Chávez, P. I., Figueroa Cárdenas, J. D., López-Cervantes, J., Barrón-Hoyos, J. M., \& MoralesRosas, I. (2013). Effect of extrusion processing parameters on anthocyanin content, physicochemical properties of nixtamalized blue corn expanded extrudates. CyTA-Journal of Food, 11(SI1), 2937. http://dx.doi.org/10.1080/19476337.2013.764929.

Fukumoto, L. R., \& Mazza, G. (2000). Assessing antioxidant and prooxidant activities of phenolic compounds. Journal of Agricultural and Food Chemistry, 48(8), 3597-3604. http://dx.doi.org/10.1021/ jf000220w. PMid:10956156.

Gomez, M. H., Waniska, R. D., \& Rooney, L. W. (1991). Starch characterization of nixtamalized corn flour. Cereal Chemistry, 68(6), 578-582. Retrieved from http://www.aaccnet.org/publications/cc/ backissues/1991/Documents/68_578.pdf

Grupo Villamex (2003). Manual de operación y mantenimiento: máquina modelo V-100 Tlayuda a 2 bandas de comales. (pp. 1-10). Guadalajara: Grupo Villamex.

He, J., \& Giusti, M. M. (2010). Anthocyanins: natural colorants with health-promoting properties. Annual Review of Food Science and Technology, 1(1), 163-187. http://dx.doi.org/10.1146/annurev. food.080708.100754. PMid:22129334.

Heinonen, I. M., Meyer, A. S., \& Frankel, E. N. (1998). Antioxidant activity of berry phenolics on human low-density lipoprotein and liposome oxidation. Journal of Agricultural and Food Chemistry, 46(10), 4107-4112. http://dx.doi.org/10.1021/jf980181c.

Juárez-Montiel, M., Ruiloba de León, S., Chávez-Camarillo, G., HernándezRodríguez, C., \& Villa-Tanaca, L. (2011). El huitlacoche (tizón del maíz), causado por el hongo fitopatógeno Ustilago maydis, como alimento funcional. Revista Iberoamericana de Micologia, 28(2), 6973. http://dx.doi.org/10.1016/j.riam.2011.01.001. PMid:21352944.
Kayacier, A., \& Singh, R. K. (2003). Textural properties of baked tortilla chips. Lebensmittel-Wissenschaft Und-Technologie, 36(5), 463-466. http://dx.doi.org/10.1016/S0023-6438(02)00222-0.

López-Martínez, L. X., \& García-Galindo, H. S. (2009). Actividad antioxidante de extractos metanólicos y acuosos de distintas variedades de maíz mexicano. Nova Scientia, 2-1 (3), 51-65. Retrieved from http://www.redalyc.org/articulo.oa?id=203314886004

López-Martínez, L. X., Oliart-Ros, R. M., Valerio-Alfaro, G., Lee, C.-H., Parkin, K. L., \& Garcia, H. S. (2009). Antioxidant activity, phenolic compounds and anthocyanins content of eighteen strains of Mexican maize. Lebensmittel-Wissenschaft Und-Technologie, 42(6), 1187-1192. http://dx.doi.org/10.1016/j.lwt.2008.10.010.

López-Martínez, L. X., Parkin, K. L., \& García, H. S. (2011). Phase II-inducing, polyphenols content and antioxidant capacity of corn (Zea mays L.) from phenotypes of white, blue, red and purple colors processed into masa and tortillas. Plant Foods for Human Nutrition, 66(1), 41-47. http://dx.doi.org/10.1007/s11130-0110210-z. PMid:21327968.

Maga, J. A., \& Liu, M. B. (1993). Hopi blue corn extrusion. Developments in Food Science, 32, 983-986.

Martínez-Flores, A., Corrales-García, J. J., Espinosa-Solares, T., GarcíaGatica, P. G., \& Villanueva-Verduzco, C. (2008). Cambios postcosecha del hongo comestible huitlacoche (Ustilago maydis (D. C.) Corda). Revista Chapingo Serie Horticultura, 14(3), 339-346. Retrieved from http://www.scielo.org.mx/pdf/rcsh/v14n3/v14n3a16.pdf

McDonough, C. M., Gomez, M. H., Rooney, L. W., \& Serna-Saldivar, S. O. (2001). Alkaline-cooked corn products. In E. W. Lusas \& L. W. Rooney (Eds.), Snack foods processing (Chap. 4, pp. 73-113). Boca Raton: CRC Press. Retrieved from http://www.crcnetbase.com/doi/ pdf/10.1201/9781420012545.ch4

Mehta, S. P. (2001). Tortilla chip processing. In E. W. Lusas \& L. W. Rooney (Eds.), Snack foods processing (Chap. 10, pp. 261-280). Boca Raton: CRC Press. Retrieved from http://www.crcnetbase.com/doi/ pdfplus/10.1201/9781420012545.ch10

México, Secretaría de Salud. (2003, August 18). Norma Oficial Mexicana NOM-187-SSA1/SCFI-2002, Productos y servicios. Masa, tortillas, tostadas y harinas preparadas para su elaboración y establecimientos donde se procesan. Especificaciones sanitarias. Información comercial. Métodos de prueba. Diario Oficial de la Federación. Retrieved from http://dof.gob.mx/nota_detalle.php?codigo $=691995 \&$ fecha $=18 / 08 / 2003$

Mora-Rochin, S., Gutiérrez-Uribe, J. A., Serna-Saldívar, S. O., SánchezPeña, P., Reyes-Moreno, C., \& Milán-Carrillo, J. (2010). Phenolic content and antioxidant activity of tortillas produced from pigmented maize processed by conventional nixtamalization or extrusion cooking. Journal of Cereal Science, 52(3), 502-508. http://dx.doi. org/10.1016/j.jcs.2010.08.010.

Nemś, A., Pęksa, A., Kucharska, A. Z., Sokół-Łętowska, A., Kita, A., Drożdż, W., \& Hamouz, K. (2015). Anthocyanin and antioxidant activity of snacks with coloured potato. Food Chemistry, 172, 175-182. http://dx.doi.org/10.1016/j.foodchem.2014.09.033. PMid:25442540.

Plascencia-González, G., Martínez-Bustos, F., Salinas-Moreno, Y., Sánchez-Sinencio, F., \& Hernández-Montes, A. (1999). Evaluation of pigmented corns in the elaboration of corn and tortilla chips using nixtamalized flours prepared by a hydrothermal process. In Proceedings of the 10th World Congress of Food Science \& Technology. Sydney, Australia.

Reis, S. F., \& Abu-Ghannam, N. (2014). Antioxidant capacity, arabinoxylans content and in vitro glycaemic index of cereal-based snacks incorporated with brewer's spent grain. Lebensmittel-Wissenschaft Und-Technologie, 55(1), 269-277. http://dx.doi.org/10.1016/j.lwt.2013.09.004. 
Rice-Evans, C. A., Miller, N. J., \& Paganga, G. (1996). Structureantioxidant activity relationships of flavonoids and phenolic acids. Free Radical Biology \& Medicine, 20(7), 933-956. http://dx.doi. org/10.1016/0891-5849(95)02227-9. PMid:8743980.

Ruiz-Herrera, J., \& Martínez-Espinoza, A. D. (1998). The fungus Ustilago maydis, from the aztec cuisine to the research laboratory. International Microbiology, 1(2), 149-158. PMid:10943353.

Salinas-Moreno, Y., \& Arellano, V. J. L. (1989). Calidad nixtamalera y tortillera de híbridos de maíz con diferente tipo de endospermo. Revista Fitotecnia Mexicana, 12, 129-135.

Salinas-Moreno, Y., Aragón Cuevas, F., Ybarra Moncada, C., Aguilar Villarreal, J., Altunar López, B., \& Sosa Montes, E. (2013). Caracterización física y composición química de razas de maíz de grano azul/morado de las regiones tropicales y subtropicales de Oaxaca. Revista Fitotecnia Mexicana, 36(1), 23-31. Retrieved from http://www.scielo.org.mx/pdf/rfm/v36n1/v36n1a3.pdf

Salinas-Moreno, Y., Martínez-Bustos, F., Soto-Hernández, M., OrtegaPaczka, R., \& Arellano-Vázquez, J. L. (2003). Effect of alkaline cooking process on anthocyanins in pigmented maize grain. Agrociência, 37(6), 617-628. Retrieved from http://www.colpos.mx/agrocien/ Bimestral/2003/nov-dic/art-7.pdf

Sánchez-Madrigal, M. A., Quintero-Ramos, A., Martínez-Bustos, F., Meléndez-Pizarro, C. O., \& Ruiz-Gutiérrez, M. G. (2014). Effect of different calcium sources on the antioxidant stability of tortilla chips from extruded and nixtamalized blue corn (Zea mays L.) flours. Food Science and Technology, 34(1), 143-149. http://dx.doi. org/10.1590/S0101-20612014000100021.

Setchell, K. D. R., \& Cassidy, A. (1999). Dietary isoflavones: biological effects and relevance to human health. The Journal of Nutrition, 129(3), 758S-767S. PMid:10082786.
Singh, R., Singh, G., \& Chauhan, G. S. (1996). Effect of incorporation of defatted soy flour on the quality of biscuits. Journal of Food Science and Technology, 33(4), 355-357.

Singleton, V. L., Orthofer, R., \& Lamuela-Raventós, R. M. (1999). Analysis of total phenols and other oxidation substrates and antioxidants by means of folin-ciocalteu reagent. Methods in Enzymology, 299, 152178. http://dx.doi.org/10.1016/S0076-6879(99)99017-1.

Valdez-Morales, M., Barry, K., Fahey, G. C. Jr, Domínguez, J., de Mejía, E. G., Valverde, M. E., \& Paredes-López, O. (2010). Effect of maize genotype, developmental stage, and cooking process on the nutraceutical potential of huitlacoche (Ustilago maydis). Food Chemistry, 119(2), 689-697. http://dx.doi.org/10.1016/j.foodchem.2009.07.015.

Valverde, M. E., Paredes-López, O., Pataky, J. K., Guevara-Lara, F., \& Pineda, T. S. (1995). Huitlacoche (Ustilago maydis) as a food source-biology, composition, and production. Critical Reviews in Food Science and Nutrition, 35(3), 191-229. http://dx.doi. org/10.1080/10408399509527699. PMid:7632354.

Vinson, J. A., Su, X., Zubik, L., \& Bose, P. (2001). Phenol antioxidant quantity and quality in foods: fruits. Journal of Agricultural and Food Chemistry, 49(11), 5315-5321. http://dx.doi.org/10.1021/ jf0009293. PMid:11714322.

Wrolstad, R. E., Durst, R. W., \& Lee, J. (2005). Tracking color and pigment changes in anthocyanin products. Trends in Food Science \& Technology, 16(9), 423-428. http://dx.doi.org/10.1016/j.tifs.2005.03.019.

Zazueta-Morales, J. J., Martínez-Bustos, F., Jacobo-Valenzuela, N., Ordorica-Falomir, C., \& Paredes-López, O. (2002). Effects of calcium hydroxide and screw speed on physicochemical characteristics of extruded blue maize. Journal of Food Science, 67(9), 3350-3358. http://dx.doi.org/10.1111/j.1365-2621.2002.tb09590.x. 